\title{
ROUNDING UP OUR JOURNEY THROUGH THE WORLD OF ORGANIZED INTERESTS IN THE POST-COMMUNIST CEE REGION
}

\author{
Michael Dobbins, Emilia Piotrowska, and Rafał Riedel
}

\section{Introduction}

In this book, we journeyed though the world of organized interests in the post-communist region. Functional systems of interest intermediation and dynamic links between the political system and civil society are important preconditions for successful democratic consolidation. In CEE, organized interests operate in a particularly fluid environment. Economic systems have undergone complete structural makeovers, political systems have been fundamentally redesigned, and policy-specific reforms have transformed pre-existing institutions to the core. The transformation on numerous fronts has opened new avenues for activity for organized interests in multiple arenas. Unlike in the communist system, where interest intermediation was channeled through the communist party and state bureaucratic apparatus, CEE interest groups now operate within parliaments, ministerial bodies, and new interest intermediation forums, while also fostering ties with government and oppositional parties. They are now free to calibrate their strategies to their needs and demands of their members and leadership, consolidate their ties with like-minded or rivaling groups, or actively lobby the public outside formal political channels.

European integration has also offered a multitude of new opportunities for interest groups from the region to gain experience and expertise from and share resources with like-minded groups abroad. However, these new openings for civil society and advocacy organizations at the transnational level have arguably coincided with closings and, to some extent, crackdowns on civil society in the countries affected by democratic backsliding. In particular, Poland and Hungary have recently experienced a re-centralization of policy-making processes, a shift away from liberal, globalist ideals, and reinvigoration of illiberal, national-conservative forces. These changes have significant implications for the functioning of 
interest groups and other civic societal actors, as they may need to adapt to the de-democratization tendencies and the re-emergence of clientelist networks.

The authors of the chapters aimed to comparatively grasp the activities, strategies, constraints, interrelationships, and concrete influence of organized interests in the region from multiple angles. To accommodate the heterogeneity of the region, the authors affiliated with the core OrgIntCEE project applied a large arsenal of qualitative and quantitative methods to the study of interest groups in three diverse policy areas - higher education, healthcare, and climate-energy which are critical for the future viability and competitiveness of four CEE countries - the Czech Republic, Hungary, Poland, and Slovenia - and beyond. Three external authors also provided detailed insights into additional dimensions, which are essential to understanding the dynamics of civil society and overall policy-making in the region: the Catholic Church, labor unions, and the interlinkages between interest groups and political parties.

The differentiated perspectives added new nuanced insights into the wellestablished perception that civil society is weak in the region, that interest organizations are inexperienced, lack professional lobbying skills, and that policy-making is mainly centralized, state-driven, and over-particized. The authors provided in-depth analysis of patterns of interest intermediation, lobbying strategies, and the broader effects of the transformation and Europeanization processes as well as domestic reform processes on populations of interest groups. In this final chapter, we wish to briefly revisit the findings of the chapters. Then we present some new data reflecting broader trends in the four countries. The new data and illustrations are also based on our survey of organized interests (see Annex). On the one hand, they offer additional support to some of the major findings of the chapters, while also painting a more comprehensive, overarching picture. They also enable us to draw some generalizable conclusions about the state of civil society, lobbying, and advocacy in the region.

\section{A review of our findings}

The first two empirical chapters contributed to the growing body of literature on organizational populations (see Berkhout \& Lowery, 2008; Nownes, 2004), while tracing the determinants for the increases and decreases of interest group populations operating in our three core policy fields - energy, healthcare, and higher education. In Chapter 2, Rafael Labanino, Michael Dobbins, and Rafał Riedel showed that "varieties of communism", spanning from the more bureaucraticauthoritarian Czech(oslovak) version to the national-accommodative versions of Hungary, Poland, and Slovenia significantly impacted communist and pretransition organizational formations. The accommodative regimes proved much more conducive to the foundation of civic organizations than the more rigid Czech(oslovak) regime, whereby periods of experimentation with economic reforms and political liberalization also boosted foundation rates. In Slovenia, by contrast, organized interests proliferated under communism. The nature of regime 
change also proved crucial, as political fragmentation, partisan competition, and increasing grassroots mobilization (e.g. in Hungary) brought about stronger formation rates than in Poland, where there was a relatively united front against the communist party. For all countries though, the authors showed that there was an at least moderate level of organizational activity under communism, and thus no "tabula rasa" during 1989-1990. In fact, for Hungary, organizations founded before 1989 are even more viable in the post-communist phase than those founded after the breakdown of communism. With their findings, the authors contribute both to the "varieties of communism" literature and to the scholarly debate about the heritage of the pre-1989 past, including the ever-existing dilemma about the sources of strength and weakness of the CEE civil societies.

In Chapter 3, Michael Dobbins, Rafael Pablo Labanino, and Brigitte Horváthová look at how organizational populations evolved after 1989. They hypothesized that organizational populations would be boosted by the transition to democracy, the European integration process as well as major domestic policyspecific reform processes, many of which are linked with Europeanization. They also argued that populations may eventually become saturated, or "densitydependent", leading to a slow-down in formations, while also providing some preliminary insights on the impact of national-conservatism or illiberal democracy in Hungary and Poland on organizational populations.

Their data show that the transition to democracy was an enormous impetus for organizational formations, but that Hungary and Slovenia - as already shown in Chapter 2 - had large pre-existing populations due to the relative openness of their anciens régimes, the ideological diversity of civic initiatives during the struggle for Slovenian nationhood, as well as the nature of regime change. The late 1990s and early to mid-2000s - marked by the European integration process and large-scale national reforms - heralded another acceleration in organizational formations. Their data also showed that "democratic backsliding", in particular in Hungary, has not provided a conducive climate for organizational formations. However, the authors also found evidence of "density-dependence" in all national-level organizational populations, making it difficult to distinguish between saturation effects and the impact of national-conservative governance. Finally, and importantly from a civil society perspective, they showed that many organizations founded in the past decade are "diffuse" civic or cause groups representing interests that otherwise are often difficult to organize due to Olson's collective action dilemma (1965). With the exception of Hungary, where the 2000-2010 decade was more favorable to such organizational formations, Poland, the Czech Republic, and Slovenia witnessed strong growth in environmental, patients' and students' organizations representing broader societal goals in the past ten years. These three countries also experienced a boom in new groups representing renewable energy businesses, while renewable organizations proliferated in the 2000-2010 period in Hungary.

In the next segment, we tackled advocacy patterns in the region from two different angles. In Chapter 4, Szczepan Czarnecki explored lobbying tactics 
in CEE. Directly tying into the distinction between "civic" and "concentrated" (i.e. business) groups elaborated on above, he explored whether group type and the nature of issues impact the lobbying strategies chosen by organized interests. His findings for CEE are largely in line with those of Binderkrantz et al. (2015) that ideationally oriented civic groups operating in the "public interest" tend to pursue "outsider" strategies. They mobilize the public by means of protests, petitions, and directly engaging with potential supporters. Yet, he also shows that they do not shy away from direct strategies targeting the parliament and government and thus apply a broader array of lobbying approaches than classical concentrated interests. Czarnecki also shows that issues matter. Groups pursuing non-divisible goals, e.g. environmental protection more frequently pursue outsider lobbying tactics, while groups with more divisible or negotiable goals prefer insiders strategies.

Chapter 5 by Michael Dobbins, Emilia Piotrowska, and Maximilian von Bronk is embedded in the literature on interest intermediation between the state and organized interests (Avdagic, 2005; Ost, 2011; Schmitter, 1989; Streeck \& Kenworthy, 2003). Building on and adapting previous classifications of corporatism by Jahn (2016) and Siaroff (1999), they explore how interests of rivaling interests groups in the healthcare sector (e.g. the medical profession, patients, healthcare workers) are channeled into policy-making. Drawing on survey data and a catalogue of indicators of "healthcare corporatism", they first aggregate scores for different groups of organizations (e.g. healthcare workers, patients) for multiple dimensions of interest intermediation (e.g. consultations with rivaling interest groups, the state, and regulatory agencies; the perceived level of policy coordination). Then they examine to what extent certain organizations dominate the policy-making process, while also providing some descriptive details on institutionalized interest intermediation forums in post-communist healthcare.

The data show that all four systems are approximately half-way towards the corporatist ideal-type of policy-making, with Slovenia in the lead, while Hungary gravitates more towards a state-centered paradigm. Poland and the Czech Republic bear stronger features of pluralism. In any case, the standardized data show that healthcare policy-making in all four countries is more consultative than in the past, although strong country variations exist regarding the intensity of consultations with different groups of organizations. Healthcare workers' organizations are more heavily involved in the Slovenian policy-making process than in other countries. Policy-making in Hungary is dominated by the medical profession, whereas the Czech and Polish systems offer more advocacy avenues for patients' organizations.

Chapter 6 authored by Szczepan Czarnecki, Emilia Piotrowska, and Rafał Riedel deals with climate and energy policies in CEE. The chapter explores the ways in which green advocacy groups gain access to the policy-making process in Poland, Hungary, Slovenia, and the Czech Republic in comparison to other organized interests operating in climate and energy policy. The authors explain patterns of access to two types of executive bodies: governing parties 
and regulatory authorities. Taking a resource-exchange perspective, they argue that access is determined by the match of supply and demand of resources, but also conditioned by various types of provided expertise, selected aspects of professionalization, and financial resources. They find that scientific expertise and a focus on fundraising is of crucial importance in accessing regulatory authorities as well as governing parties. Focusing on human resources and organizational development as well as acquired EU funds turn out to be less relevant factors.

Chapter 7 written by Brigitte Horváthová and Michael Dobbins also deals with CEE healthcare from a different angle by exploring the characteristics of individual interest organizations, which enable their access to policy-makers. They hypothesize that financial and human resources, specialized expertise, the level of professionalization, and longevity enhance the position of interest groups. They also test Olson's (1965) classic hypothesis that concentrated groups (here the medical profession) are at an advantage over more diffuse groups (i.e. patients).

They first present an array of descriptive and comparative statistical data from our standardized survey reflecting the perceived influence of groups, their venues of political access, and their activities aimed at organizational professionalization. Their ordinal logistic regression analyses show that human resources, i.e. employed staff and membership, are key determinants of access to governmental policy-makers, whereas the financial strength of an organization does not play a significant role. Horváthová and Dobbins also show that factors such as expertise and, in particular, organizational professionalization tend to be more important than finances. Particularly noteworthy is their finding that inter-organizational cooperation, which generally is somewhat underdeveloped in CEE (see below), strongly facilitates access to policy-makers.

Chapter $\mathbf{8}$ by Aleš Vlk, Michael Dobbins, and Rafał Riedel is one of the first analyses of higher education policy in the context of post-communist national-conservatism, democratic backsliding, and other forms of authoritarian populism. They address an empirical puzzle from a stakeholder perspective: despite very similar starting points, why has Polish higher education recently experienced a significant degree of centralization, while Czech academics have largely preserved their tradition of internal stakeholder democracy? For Poland, they show that university rectors, who are well-organized in the Rectors' Conference (KRASP) and numerous other governing bodies, exploited their organizational advantage over more diffused other academic interest representations. A coalescence of rectors' interests with those of the state seeking to impose more hierarchical, managerial governance structures simultaneously enabled the government to re-assert control over the sector. The reform not only re-organized university governance by endowing rectors with unprecedented power at the cost of other previously influential, yet fragmented stakeholder groups, but also places more power in the hands of politicians.

In the Czech Republic, rectors and other high-ranking stakeholders have successfully carried out a balancing act between the political sphere (i.e. through 
parliamentary mandates) and their universities. Together with the extreme degree of inter-university decentralization, this has had the effect that Czech rectors have not succeeded centralizing their institutions. Instead, corporatist, stakeholder-oriented governance structures have been upheld.

Chapter 9, written by Rafał Riedel and Szczepan Czarnecki, deals with the intersections of two processes, namely Europeanization and professionalization. The analysis explores how the EU impacts the level of professionalization of CEE interest groups, as understood in the classical top-down Europeanization approaches, while also addressing how other types of Europeanization (e.g. cross-loading through trans-border exchange with like-minded groups) affect their level of professionalization. The key finding is that various types of Europeanization pressures produce diversified outcomes regarding the professionalization of organized interests. Counter-intuitively, it is not membership in supranational umbrella organizations (i.e. a standard parameter of Europeanization) or funding from EU-level interest organizations that necessarily lead to professionalization, rather to a much greater extent strong ties with like-minded EU organizations. Thus, the results show that cross-loading Europeanization mechanisms such as transnational communication and linkages are a stronger catalyst for organizational development than traditional top-down or bottom-up mechanisms.

Chapter 10 authored by Tomasz Kubin focuses on labor unions, which are an essential part of the ecosystem of organized interests. He explores how coal mining unions justify and lobby their standpoints on EU climate and energy policies. Specifically, he addresses why the Polish government consistently has refused to declare climate neutrality as a long-term goal, while the Czech government changed its position at the European Council meeting in December 2019. He shows that the position of coal mining trade unions towards EU climate and energy policy is clearly negative and that they use arguments that go beyond the interests of the mining sector. Hence, they aim to convey the impression that they also act in the interest of other social groups. In other words, the tactics adopted by trade unions are not based on "silencing" the issue and achieving their goals "quietly", rather on "going public" with their positions and arguments. Kubin provides an important case study analysis describing and explaining the lobbying tactics adopted in a sector that is strategically essential for the carbon-dependent economies of numerous CEE states.

Joanna Kulska provides another interesting Polish-Czech comparison in Chapter 11. She focuses on the Catholic Church, which holds extremely different positions in Poland (where it is exceptionally strong and influential) and the Czech Republic (where it is weak and marginal). The author analyzes the evolving role, goals, and strategies applied by the Church, taking into consideration the significantly different positions of religion in the social-political contexts of both countries. The analysis places itself in the increasingly developing strand of research in comparative politics emphasizing the role of cultural and, more specifically, religious determinants in explaining policy-making. In the highly illustrative Polish 
case, the state and church exhibit extraordinarily close bonds, through which both sides exploit their mutual dependence. She also addresses how the Catholic Church relates to a "darker side" of civil society and illiberal democracy in general. Once a key part of the democratic transformation, the process of pluralization and the building of a strong, active, and independent sphere of engaged citizens challenging the state, some segments of civil society are now turning away from those values. Instead, this illiberal civil society leans towards authoritarian forces promoting top-down processes of building alternative organizations and movements supportive of government policies (Ekiert, 2019). In Poland, this has already resulted in the adoption of new financing rules for NGOs and the support for organizations with a more nationalist and Roman Catholic profile (Mandes, 2020). The semi-authoritarian populists ruling in Poland use Catholicism as a political ideology, and the Polish Catholic Church entertains its influential position in the political system dominated by (so-called) Christian and conservative forces. This mutually inter-dependent constellation produces political outcomes that endanger the liberal democratic order and free, pluralistic civic society.

Last but not least, Chapter 12 by Paweł Kamiński contributes to the stream of literature claiming that associative democracy is vital for the health and stability of representative and accountable democratic governments. He follows the recognized wisdom that political parties and interest groups are the two most important actors functioning as "transmission belts" between the public and the state, bringing citizens' demands to the political agenda. He explores whether interest groups "compensate" in representing citizens in policy areas left open by political parties, or quite contrary, whether they follow the same pattern of biased representation and indifference towards civil society. Using quantitative and comparative data gathered between 2016 and 2018 from three "old" and "new" member states, respectively, he sheds light on the interplay between interest groups and political parties in the context of civic engagement. His essential conclusion is that in the vast majority of the analyzed countries, interest groups occupy positions neglected by political parties.

\section{Some final general trends}

To wrap up, we now briefly revisit our survey data and present some simple comparative figures. This will enable us to detect various country-specific trends, while also addressing the strengths and weaknesses in the consolidation of mature interest group systems in CEE. We do not wish to engage in new in-depth causal analysis, rather simply outline some broader characteristics of the development of interest groups and interest intermediation systems in the region. In doing so, we return to four main dimensions in interest group studies, which the book has covered - the ecosystem dimension, coordination/consultation dimension, ${ }^{1}$ access and power dimension, and professionalization dimension.

For this final overview, we simply aggregated all responses to various survey questions by country. We excluded responding organizations with less than 
50 individual members or 10 business or institutional members so that the data only reflect the perceptions of mid-sized or larger organizations that are more predestined to be involved in the policy-making process.

First, returning to the opening chapters, we address the ecosystem dimension. We asked our respondents about changes in the number of organizations and their membership over time:

In your opinion, is the number of interest organizations attempting to influence decision-making and legislation in your area increasing, decreasing, or stable over the past 10-15 years? ( 1 - strongly decreasing, 2 - decreasing, 3 - the same, 4 - increasing, 5 - strongly increasing)

The illustration largely confirms the finding of Dobbins et al. (2020) (Chapter 3) that organizational populations have become more or less "saturated" and that the main periods of foundational activity lie in the past (the immediate transformation phase, the Europeanization phase of the late 1990s and 2000s). While we do see some slight bumps, the aggregated results point to a relatively stable playing field with only slight increases in new foundations, despite different points of departure in terms of pre-existing organized interests under communism (see Chapters 2 and 3). Yet, if we ask whether individual organizations' membership is increasing or decreasing over time, we see slightly stronger dynamics (Figure 13.1).

How has the size of your organization's membership changed in the past 10-15 years (or since its founding, if founded more recently)? (1- much less, 2 - less, 3 the same, 4 - more, 5 - much more)

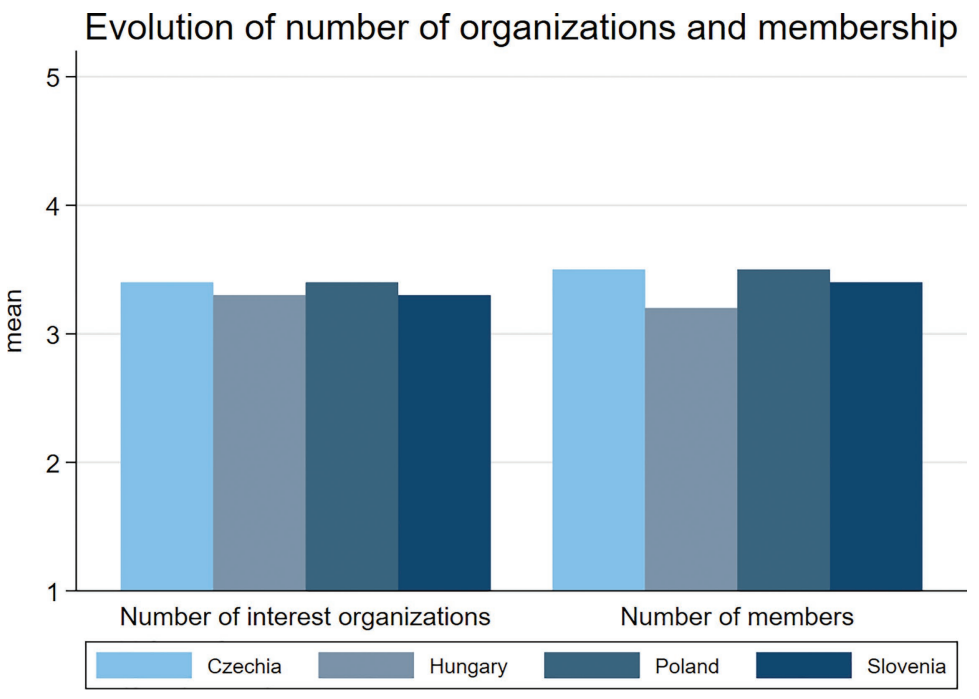

FIGURE 13.1 Perception of increases in the number and size of interest groups. 
Across the board, responding organizations report that their membership bases are growing, even in Hungary where only few new organizations have been founded in our policy areas since 2010 (see Chapter 3) and policy-making tends to be carried out in closed technocratic state-industry circles (see Horváthová \& Dobbins, 2019 for energy policy; see Chapter 5 for healthcare). Yet altogether, we do see notable changes over time in terms of interest group expansion and mobilization.

Second, we look at the coordination and consultation dimension to address the intensity of deliberations, the points of contact of organizations as well as advocacy structures. One key indicator of an effective interest intermediation system, and in particular those of a corporatist type, are targeted efforts to bring rivaling organizations to the table to jointly coordinate policy. We therefore asked:

How would you rate the level of policy coordination/political exchange between the state and your interest group? (1 - very weak, 2 - weak, 3 - moderate, 4 strong, 5 - very strong)

Most groups indicated a relatively low level, shedding doubt on corporatist-like policy-making. However, the scores do rise somewhat if we exclusively look at umbrella organizations (for a more nuanced picture of healthcare, see Chapter 5 in this volume; for energy policy interest intermediation, see Horváthová et al. forthcoming, for higher education, see Dobbins et al., forthcoming; for labor policy, Rozbicka et al., 2020).

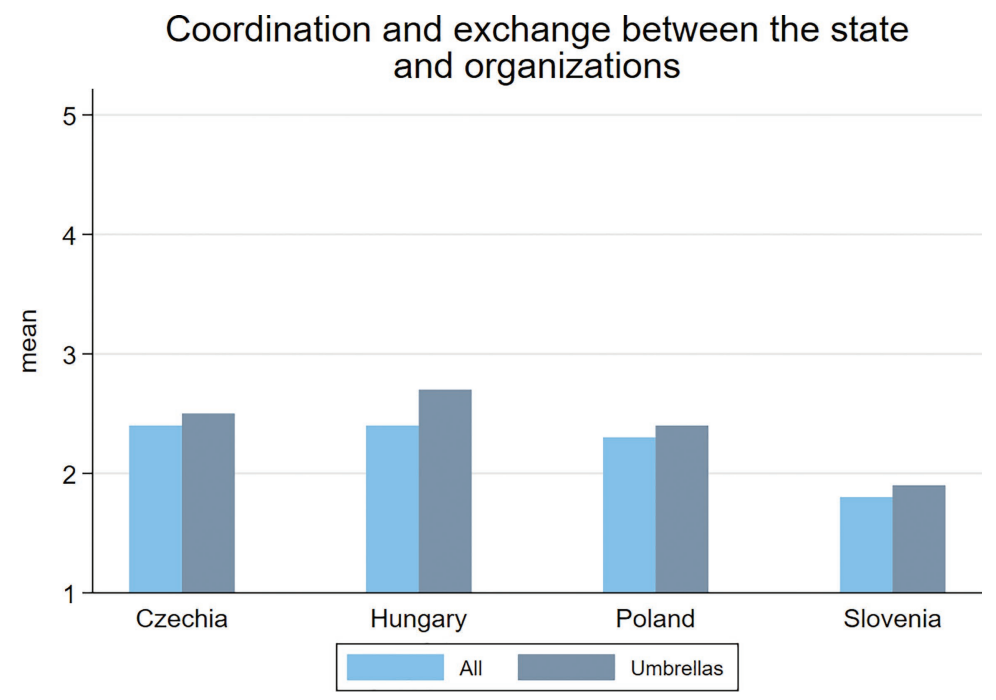

FIGURE 13.2 Perception of the level of policy coordination between the state and organizations. 
Particularly interesting is the very low score for Slovenia, which contradicts Jahn's (2016) classification of Slovenia as the most corporatist country in CEE, at least in socio-economic policy-making. While Slovenia did receive the highest score for "healthcare corporatism" (see Chapter 5), respondents pointed out that coordination often takes place among the medical profession outside the state. Moreover, there exist many smaller patients' groups without large umbrella organizations speaking for patients with one voice. In both healthcare and higher education (see Dobbins et al., forthcoming), numerous well-established workers' organizations compete for influence over wages and working conditions. For healthcare, this takes place within the Economic and Social Council (ESC), whereas for higher education, there is no formalized platform for such coordination. Moreover, Slovenia exhibits an enormous diversity of student and academic interest groups (see Chapter 3), making joint policy coordination among all of them enormously difficult. This, therefore, may explain the strikingly weak perception of policy coordination.

Remaining within the consultation/coordination dimension, we also explored the intensity of contacts between interest organizations and various political institutions, which in turn enables us to assess what public bodies they calibrate their strategies towards. We asked:

In the last five years, approximately how many times did the government consult interest groups in your field of activity? (1 - never, 2 - annually, 3 - bi-annually, 4 - monthly, 5 - weekly)

Approximately how often does your organization consult with regulatory authorities in your field of activity? (1 - never, 2 - annually, 3 - bi-annually, 4 monthly, 5 - weekly)

Approximately how often does your organization consult with political parties? (1 - never, 2 - annually, 3 - bi-annually, 4 - monthly, 5 - weekly)

As a reflection of a more mature interest intermediation system and consensusoriented, corporatist policy-making (see also Chapter 5), we inquired whether organizations regularly consult organizations with opposed or rivaling positions.

Approximately how often does your organization consult with organizations representing opposing interests? (1 - never, 2 - annually, 3 - bi-annually, 4 monthly, 5 - weekly)

In terms of consultations with governments and rivaling interest groups, annual to bi-annual consultations seem to be the prevalent norm, whereas regulatory authorities seem to be a major point of contact. Particularly eye-catching is the weak degree of interactions with political parties in all countries, in particular in Hungary (and with the partial exception of the Czech Republic). This indeed lends additional support to Kamiński's argument (see Chapter 12) that organized interests in the region ${ }^{2}$ are occupying political and territory which political parties are abandoning. In other words, there seems to be a pronounced deficit when 


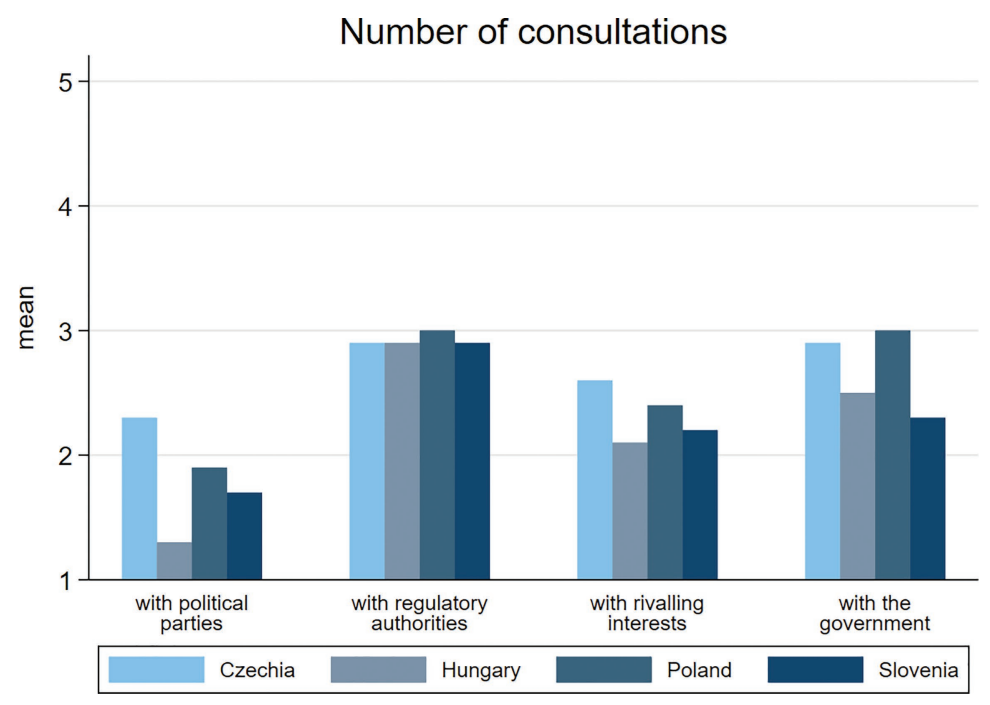

FIGURE 13.3 Frequency of consultations between organizations, political bodies, and rivaling organizations.

it comes to collective mobilization and strategic coordination between parties and civil society organizations, with both apparently constituting two separate venues of political advocacy.

This impression is somewhat reinforced when it comes to our data on cooperation between organized interests. Not only is strong cooperation and coalitionbuilding between like-minded organizations a sign of a well-developed system of advocacy and interest intermediation, but also a key variable for the success of interest groups in reaching their objectives (Junk, 2020; Klüver, 2011; Mahoney, 2007). We asked:

How frequently does your organization cooperate with other interest organizations in fundraising/representation on advisory boards/joint statements/joint political strategies? ( 1 - never, 2 - occasionally, 3 - frequently)

Other than fundraising, which appears to remain the domain of individual organizations, we see relatively strong dynamics in strategic cooperation between organizations. Interestingly, Hungarian organizations are somewhat more cooperative than others, at least regarding joint strategies. We would postulate that this is an effect of the generally weaker access to political institutions, forcing organizations into joint coordination.

Now let us look at how organizations fare in country comparison on the power and access dimension. We asked:

How difficult is it for your organization to access governing parties/opposition parties/ regulatory authorities? (1 - very difficult, 2 - difficult, 3 - moderate, 4 - easy, 5 - very easy) 
How would you describe your level of participation in parliamentary hearings/ parliamentary committees? (1 - no participation, 2 - low participation, 3 occasional participation, 4 - high participation, 5 - very high participation)

Particularly shocking is the finding for Hungary where ties between interest groups and the governing party (Fidesz) are effectively non-existent, and organizations tend to lobby oppositional parties while also neglecting the National Assembly.

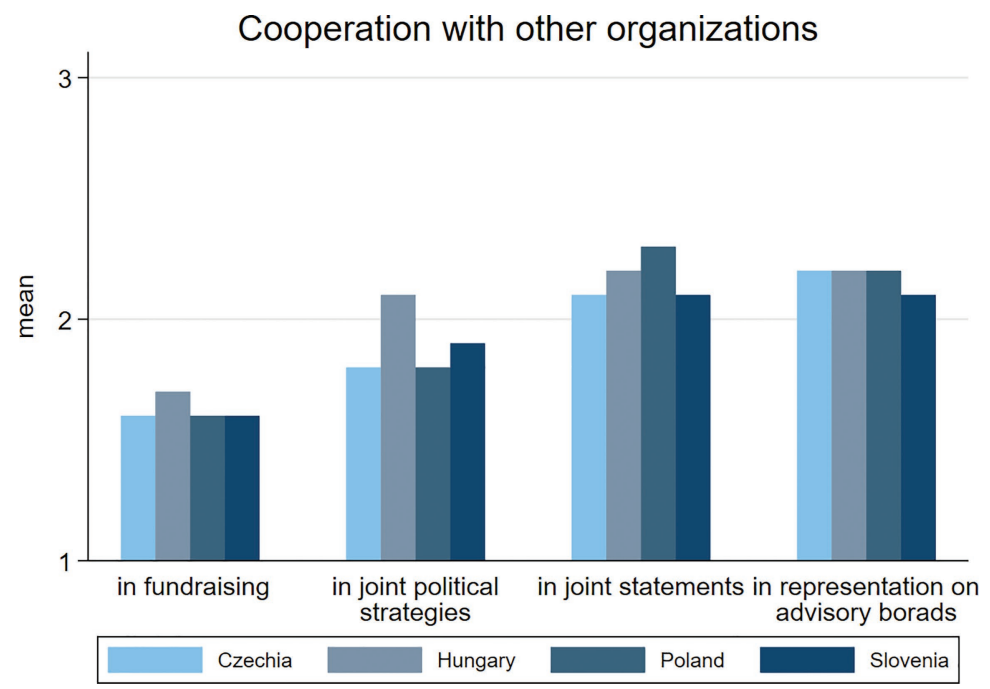

FIGURE 13.4 Willingness to cooperate with other organizations.

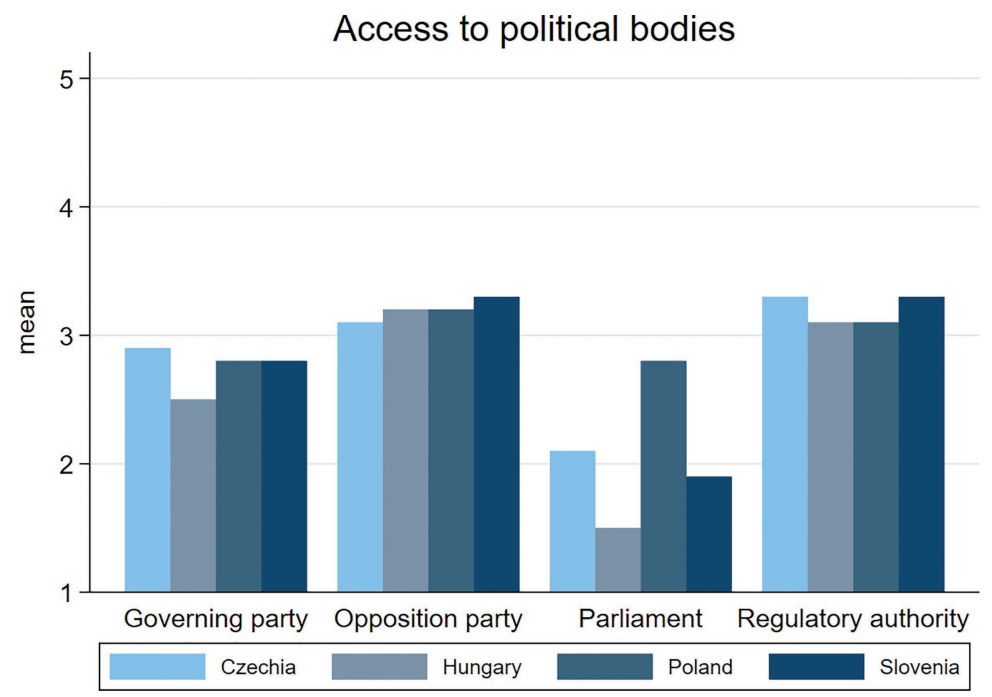

FIGURE 13.5 Perception of ease of access to political bodies by organizations. 
These general results also lend evidence of a shift towards de-parliamentarization across CEE, which is (to some extent, as underlined by the Europeanization literature) also a result of the supranationalization of lobbying activities and transferring of advocacy activities to Brussels (see Fink-Hafner, 2011). However, the Polish case is significantly different with the parliament as a main venue for interest intermediation, and with organizations targeting all political institutions equally.

To further grasp the power and access dimension, we asked organizations how they perceive their own opportunity structures vis-à-vis those of others and whether they assess their opportunities to influence policy more favorably than 10-15 years ago:

Do you think that opportunities for participation in the policy process are equally distributed among interest organizations? (1 - very much to the favor of other organizations, 2 - somewhat to the favor of other organizations, 3 - equally distributed, 4 - somewhat to the favor of our organization, 5 - very much to the favor of our organization)

To what extent do you assess the ability of your organization to assert its interests as opposed to 10-15 years ago (or since its founding, if founded more recently)? (1much less than before, 2 - less than before, 3 - the same, 4 - greater now, 5 - much greater now)

Do you experience intensive competition from organizations active in your field that represent opposing interests or values? 1 - much less than before, 2 - less than before, 3 - the same, 4 - greater now, 5 - much greater now)

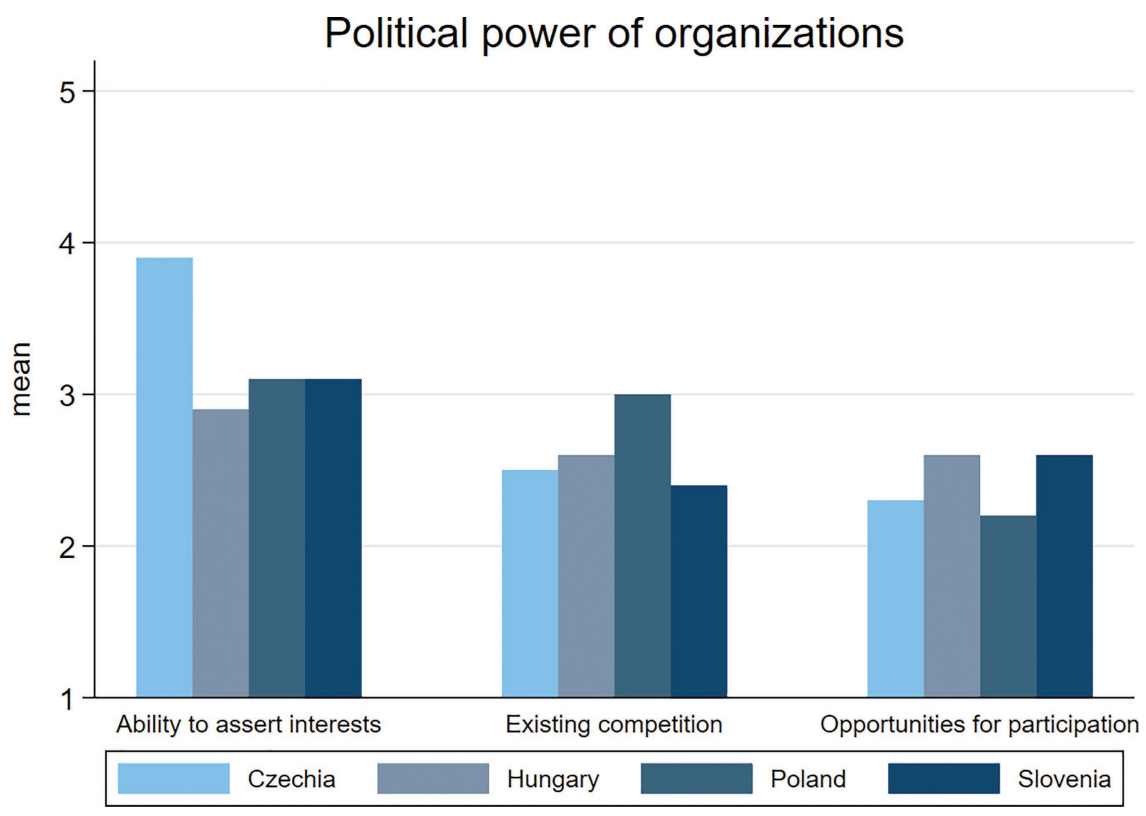

FIGURE 13.6 Perception of opportunity structures and influence. 
The data again appear to confirm that the organizational playing fields have become rather consolidated (see ecosystem dimension above). At least with respect to perceived competition from similar organizations, we do not see an Americanlike system of dynamic competition among rivaling interest organizations in any of the countries, except to a limited extent in Poland. Unsurprisingly, organizations tend to subjectively report that their opportunities for participation and thus influence as worse than their rivals (Slovenia and Hungary to a lesser extent). However, when we ask directly about their perceived influence, the data paint a relatively positive picture, with Czech organizations visibly more optimistic than others. Yet, Polish and Slovenian organizations also (aggregately) evaluate their opportunities relatively favorably.

Turning back to Chapter 9, we also present some simple final data on the professionalization dimension based on their own assessments. We asked:

To what extent does your organization focus on the following activities as opposed to 10-15 years ago (or since its founding, if founded more recently): organizational development/HR development / training of lobbyists/fundraising/evaluation of efficiency and effectiveness/strategic planning? (1 - much less, 2 - less, 3 - the same, 4 - more, 5 - much more)

We see that organizations across CEE are becoming more and more professionalized, with a leading position of Slovenian groups and Hungarian groups as slight laggards. At the same time, especially in the democratically backsliding countries, we observe a growing aversion to lobbying, which may be the result of the anti-elitist mood of the authoritarian populist politics, but is worthy of further exploration. Importantly though, the chapters showed that the role of

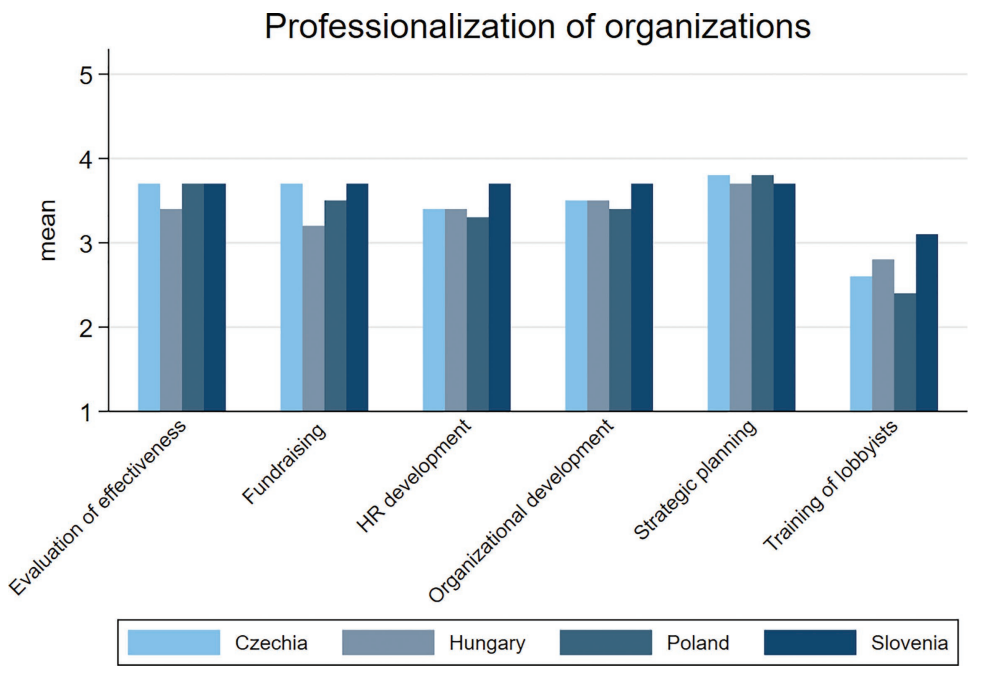

FIGURE 13.7 Various aspects of professionalization of organizations. 
professionalization in facilitating access to policy-makers is not the same. While Horváthová and Dobbins determined in Chapter 7 that professionalization together with inter-organizational cooperation (see above) - provides a key for healthcare groups to access policy-makers, Chapter 6 by Szczepan Czarnecki, Rafał Riedel, and Emilia Piotrowska revealed that resources, and in particular financial capacity, are more central to political access than professionalization. In either case though, our data reflect an increasing activity in all aspects of professionalization, which our survey covered.

\section{Pathways for future research}

The newly generated data and analyses presented in this book shed new light on the current status of state-civil society relationships in post-communist CEE and in particular interest groups as key representatives of civil society. Despite this increasingly complete picture, we encourage scholars to conduct further research to fully grasp the dynamically changing ecosystems and playing fields of organized interests in the region.

Apart from the observed deficit in the scholarly interest dedicated to postcommunist organized interests, which we wished to overcome with this book, we are also witnessing significant changes to the liberal democratic status quo in CEE, which constitutes a salient contextual variable for any analysis of the subject matter. The champions of the 1989 pro-democratic transition, most spectacularly Hungary, but to some extent also Poland, have taken a U-turn towards the still poorly understood realm of illiberal democracy. Amid encroachments on the rule of law, civil rights and free civil society in general have increasingly been questioned or gradually replaced by illiberal forms of civil society engagement (see Kulska in this volume). Clientelistic networks of inter-dependence between and among the state and societal actors are arguably also undermining the healthy advocacy process. No matter if they manifest themselves in oligarchic mafia state-like forms observed in Hungary (Magyar, 2016), or softer versions of Polish semi-authoritarianism, they are generally hostile to a well-functioning civic society. Ever more centralized policy-making and the state-driven, over-particized decision-making process create an unfavorable environment for balanced advocacy and lobbying activities. Thus, before CEE interest intermediation systems reached their potential and full maturity, they have arguably started to erode under the influence of the democratic backsliding tendencies. These patterns are worth scholarly investigation, enabling deeper explanations of various aspects of CEE civil society developments. This applies in particular to Olejnik's (2020) argument on the preferential treatment of state-subsidized groups, for which we were only able to provide inconclusive counter-evidence, or organized interests representing state-owned enterprises (see Kubin in this volume).

Tying into this, future studies should focus more on the territorial dimension of lobbying in the region. One interesting question is whether the increasing centralization of policy-making in numerous CEE countries is prompting organized 
interests to increasingly target their advocacy activities at the European or regional level, or whether they react to political centralization by expanding their national-level activity. Along these lines, scholars should also address what interest group-related factors (see Chapters 6 and 7) best enable organized interests to operate simultaneously on multiple territorial levels and, in turn, how this affects their ability to shape policy. In other words, national and transnational "venue shopping" should be give more attention. While transnational lobbying is heavily contingent on the specific policy areas and incentives (see Chapter 9), it may also be equally influenced by domestic political dynamics and the openness or closure of political systems.

The analyses collected in this volume also challenged a number of wellestablished claims present in the literature, most notably the "weak civil society hypothesis", as reflected in inexperienced interest organizations lacking professional lobbying skills (see Guasti, 2016; Howard, 2003). We show that CEE countries differ not only at the point of arrival, but also at the very point of departure understood as the beginning of transition processes, laying the foundations for various systems of interest representation. The precise picture is much more nuanced and shows many ways in which the country-specific or sector-specific characteristics of civic society manifest themselves in CEE. In this book, we provided a better understanding of the conditions of policy-making processes from the interest groups perspective as important players in post-communist democracies. We did so by comparatively exploring their position, structures, status, and patterns of behaviors, taking into account interest group-related factors, issuerelated factors, socio-economic institutions, and aspects of Europeanization.

Apart from the provided in-depth analysis of patterns of interest intermediation, lobbying strategies, and the broader effects of the transformation and Europeanization processes as well as domestic reform processes on populations of interest groups, more research is imperative in all of the above-mentioned areas based on both qualitative and quantitative (as well as mixed) methods. This applies not only to the expansion of the countries but also to policy areas covered. Scholars should also focus more on the advocacy and lobbying tools used by organized interests, their communication strategies, as well as new social and protest movements. In addition, scholars of the region should integrate other variables for interest group success, which have also proven to hold strong explanatory value in recent interest group research. These include not only, for example, the size of coalitions (Junk, 2020; Mahoney, 2007), but also public opinion, the framing of issues (Rasch, 2018), the polarization of preferences (Bunea, 2013), and whether organizations are wishing to preserve or modify the status quo. Thus, a stronger focus on specific issues, their salience, and the public and organized group coalitions shaping policy would strongly enhance our understanding of lobbying and advocacy in the region.

Another important stream of research worth further scientific exploration is the public (mis)perceptions of various forms of organized interests. Relatively little research addresses how the various forms of advocacy and lobbying are 
welcomed or rejected by the public. These questions are of vital importance for the legitimacy and accountability of organized interests and their role and place in the socio-political system. Looking beyond our data on organizational professionalization, scholars should delve deeper into the internal dynamics of CEE interest groups and explore how they are governed internally, how they recruit and maintain their members, how they formulate their policy positions, and to what extent internal democratic decision-making has been institutionalized. Last but not least, comparative analyses between the consolidated western systems of interest intermediation and post-communist systems are highly desirable. Cross-country and cross-sectoral analyses exploring diversified similarities and differences between and among organized interests would provide a full(er) picture of the European advocacy and lobbying systems.

\section{Notes}

1 Also denoted as the functional dimension in Chapter 5.

2 His analysis deals with Poland, Slovenia, Lithuania and covers interest organizations from more policy areas.

\section{References}

Avdagic, S. (2005). State-labour relations in East Central Europe: Explaining variations in union effectiveness, Socio-Economic Review 3(1), 25-53.

Berkhout, J. \& Lowery, D. (2008). Counting organized interests in the European Union: A comparison of data sources, Journal of European Public Policy 15(4), 489-513.

Binderkrantz, A. S., Christiansen, P. M., \& Pedersen, H. H. (2015). Interest group access to the bureaucracy, parliament, and the media, Governance 28(1), 95-112. doi: 10.1111/ gove.12089

Bunea, A. (2013). Issues, preferences and ties: Determinants of interest groups' preference attainment in the EU environmental policy, Journal of European Public Policy 20(4), $552-570$.

Dobbins, M., Horváthová, B., \& Labanino, R. (2020). Exploring interest intermediation in Central and Eastern Europe: Is higher education different?. Unpublished Manuscript.

Ekiert, G. (2019). The Dark Side of Civil Society, Retrieved from http://conciliumcivitas. pl/the-dark-side-of-civil-society/ (Accessed 20 August 2020).

Fink-Hafner, D. (2011). Interest representation and post-communist parliaments over two decades, The Journal of Legislative Studies 17(2), 215-233.

Guasti, P. (2016). Development of citizen participation in Central and Eastern Europe after the EU enlargement and economic crises, Communist and Post-Communist Studies 49(3), 219-231.

Horváthová, B. \& Dobbins, M. (2019). Organized interests in the energy sector: A comparative study of the influence of interest groups in Czechia and Hungary, Politics and Governance 7(1), 139-151.

Horváthová, B., Dobbins, M., \& Labanino, R. (forthcoming). Towards energy policy corporatism in Central and Eastern Europe. Unpublished Manuscript.

Howard, M. D. (2003). The Weakness of Civil Society in Post-Communist Europe. Cambridge: Cambridge University Press. 
Jahn, D. (2016). Changing of the guard: Trends in corporatist arrangements in 42 highly industrialized societies from 1960 to 2010, Socio-Economic Review 14(1), 47-71. doi: 10.1023/A:1004385005999

Junk, W. M. (2020). Synergies in lobbying? Conceptualizing and measuring lobbying coalitions to study interest group strategies, access, and influence. Interest Groups and Advocacy 9, 21-37.

Klüver, H. (2011). The contextual nature of lobbying: Explaining lobbying success in the European Union. European Union Politics 12(4), 483-506.

Magyar, B. (2016). Post-Communist Mafia State: The Case of Hungary. Budapest: Central European University Press.

Mahoney, C. (2007). Explaining lobbying success in the United States and European Union. Journal of Public Policy 27(1), 35-56.

Mandes, S. (2020). Clerical sexual abuse in illiberal state: The case of Poland. Journal of State and Church 62(1), 110-134.

Nownes, A. J. (2004). The population ecology of interest group formation: Mobilizing for gay and lesbian rights in the United States, 1950-98, British Journal of Political Science 34(1), 49-67. doi: 10.1017/S0007123403000346

Olejnik, M. (2020). A new model of corporatism in states governed by populist political parties: The cases of Poland and Hungary, Czech Journal of Political Science 2, 178-195.

Olson, M. (1965). The logic of collective action: Public goods and the theory of groups. Cambridge: Harvard University Press.

Ost, D. (2011). 'Illusory Corporatism' ten years later, Warsaw Forum of Economic Sociology 2(3), 19-49.

Rasch, D. (2018). Lobbying Success in the European Union. The Role of Information and Frames. Abington: Routledge.

Rozbicka, P., Kamiński, P., Novak, M., \& Jankauskaite, V. (2020). Achieving Democracy through Interest Representation: Interest Groups in Central and Eastern Europe. Basingstoke: Palgrave.

Schmitter, P. C. (1989). Corporatism is dead! Long live corporatism!, Government and Opposition 24(1). doi: 10.1111/j.1477-7053.1989.tb00107.x

Siaroff, A. (1999). Corporatism in 24 industrial democracies: Meaning and measurement, European Journal of Political Research 36(2), 175-205. doi: 10.1111/1475-6765.00467

Streeck, W. \& Kenworthy, L. (2003). Theories and practices of neocorporatism. In: Janoski, T., Alford, R., Hicks, A., Schwartz, M. (Eds.), The Handbook of Political Sociology, Cambridge: Cambridge University Press, 441-460. doi: 10.1017/CBO9780511818059 